\title{
Funding alternatives and business planning in family businesses
}

\begin{abstract}
Family businesses form the backbone of the SME sector in every country. Those founding a new business entity usually need support from their family members, let it be their knowledge, money, assets, time, or simply understanding and personal care. Thus, it is vital to enhance not only the survival, but also the success rate of these firms. This paper reviews issues that entrepreneurs will face as a top-manager in a family business context. We assess alternatives to common financial accounting and performance measurement practices and compare adequate financing sources and strategies for family businesses to practices used by other types of firms.

The paper discusses the different forms of funds that are available to the owners of these enterprises. We will start with a brief characterization of the ownership structure of family businesses. Then review the literature on funding resources to family businesses. These different resources are discussed from a family relevant practical point of view. Finally, some conclusions are presented.
\end{abstract}

Key words: family business, financing, business planning

\section{Ownership structure of family firms}

Regarding their business setup, families may hold their company in one form of a range of ownership structures (Goel-He- Karri 2011). The most common are the following:

\footnotetext{
1 PhD Habil, associate professor, Budapest Business School; e-mail: sagi.judit@uni-bge.hu.

2 PhD, associate professor, Corvinus University; e-mail: peter. juhasz@uni-corvinus.hu.

DOI: http://dx.doi.org/10.31570/Prosp 2019012 .
} 
(1) Direct ownership. Family members hold the shares of the family business.

(2) Family holding company. The family members own shares in a single holding company, which owns family-related business as subsidiaries.

(3) Pyramidal structure. The main holding company holds shares in some other firms that own other subsidiaries.

(4) Cross-holding. Family members own shares in several companies personally but these companies have also cross ownerships among them.

Family firms are typically owned by just a few shareholders. For example, the majority (76\%) of family firms in Slovenia have a single owner, while 18 percent of them are owned by individuals (Vadnjal-Kociper-Letonja 2010).

La Porta et al. (1997) emphasise that the legal system of a country would have a strong influence on the ownership structure. While civil law countries usually offer limited protection to minority shareholders, common law protects them more extensively. This is why, in civil law countries families tend to hold bigger proportion of their businesses (greater concentration of ownership), while common law countries have higher ownership dispersion.

\section{The literature on family business finances}

Although the interest in family business research has been growing rapidly, the area of financing decisions is under-researched. In this paper reviewing the literature we will devote special attention to give a summary of the main results on the special family business related issues in financing decisions.

Motylska-Kuzma (2017) points out that despite the fact that the vast majority of the studies on financial decisions in family firms is focused on the capital structure, they do not give clear answers to the question of how family businesses behave in this scope and what their true financial logic or motivation might be.

The relevant literature [see for example Basco (2015)] emphasises the family business' unique bundle of resources, as the presence of family members alters organizational objectives and incentives and thus affects firm decision making. This, in turn, influences how family firms interact economically and socially with their environment.

Company growth and development depend not only on the stock of capital and production factors but also on who owns and works with them (Heidrich et al. 2016). Specifically, family ownership and the management regime alter how an organization is governed and managed because decisions are made in a specific organizational and pro- 
ductive framework (Jaskiewicz-Luchak 2013). This framework emerges from the contrast between family logic and business logic with different types of member affiliation (i. e., birth versus qualification), aims (i. e., family-oriented goals versus business-oriented goals), legitimacy (welfare versus rational myth), and dominance (i. e., traditions versus rational views) (Pérez Rodríguez-Basco 2011). Consequently, decision making differs between family firms and non-family firms in areas such as equity financing, corporate diversification, level of debt, innovation, risk, internationalization, and general and specific management practices, among others (Kiss-Kuba, 2009). Therefore, if decision making is affected by the type of ownership and management regime, then the ownership and management regime may have an effect at the firm level, such as on firm performance and efficiency in the use of production factors (Basco 2014; Stafford et al. 2013; Haynes et al. 1999).

In case of family-owned firms, it is usual to encounter concentrated ownership. If the majority of the shares is held by a single entity or a closely related group, then we expect strong control over the management and an intense focus on shareholder value creation that increases the stock price even for non-family members. At the same time, concentrated ownership may offer the possibility for the majority owner to divert some of the income belonging to minority owners to his own gain. This is why the way in which concentrated ownership influences the stock price (reflecting the value for minority shareholders) is not straightforward. Earlier estimates ended up with a discount of 5 to 10.5 percent on minority stakes due to concentrated ownership (Villalonga-Amit 2006).

Villalonga and Amit (2006) examined Fortune 500 firms between 1994 and 2000 to identify any value effect of family ownership. They concluded that family ownership alone did not generate value, but the founder serving as a CEO or as a chairperson - if a non-family member CEO were hired - added significant value compared to nonfamily firms. This calls for applying a 25 percent founder-manager premium for these companies based on their estimation. This positive effect more than counterbalances the negative effect of concentrated ownership.

Still, this positive effect is confirmed only for the first generation. They also found that any shareholder-CEO conflict is costlier for companies with a descendant-CEO than in nonfamily firms.

Baek and Kim (2015) emphasise that the positive 'founder effect' of family businesses is only statistically significant for the firms with a cofounder involved. They analysed more than 17 thousand US companies for the period 1996-2010. They argued that the positive effect was due to the fact that the involvement of a cofounder reduces the so 
called key person risk by offering a possible replacement for the founder, if needed, and is mitigating the negative effect of concentrated ownership. Based on this result the additional coordination costs raised by several founders are more than counterbalanced by these positive effects.

Sometimes family ownership appears to have negative effect on firm value. Lins, Volpin, and Wagner (2013) studied 8500 firms in 35 countries for the years 2008-2009 to see how family control affects valuation. They concluded, that family businesses underperformed other companies during the financial crises and cut back more on investments than other firms. The higher the underperformance was, the higher the cuts on investments were. They also concluded that in case of family-owned businesses liquidity shocks are more likely to be passed on within the group.

Lins, Volpin, and Wagner (2013) argue that family owned businesses tended to be under-diversified and this may jeopardise the survival of the enterprise during hard and liquidity demanding periods. Actions to save the company and thus the family fortune keeping the company under family control, often imply such management decisions that may reduce value for minority shareholders. Due to that, the costs of family ownership outweigh the benefits of it during crisis times (Eleni et al. 2007).

Techniques that reduce the control rights of the non-family member owners (e. g. dual share classes, pyramids, and voting agreements) had a negative effect on the share price. So, we should consider the possible existence of an ownership structure discount (Villalonga-Amit 2006).

Reilly (2016) emphasised the importance of separating the personal goodwill of the entrepreneur from that of the firm itself when valuing a family business. This might be important in the various (gift, estate, transfer, income) tax issues that might emerge. In most cases when we perform an appraisal for a family-owned company we not only do have to calculate the total value of the firm (V) and the equity (E), but also have to quantify what is the part of the current value that is attributable to the current individual owning the entity. This later value could be lost completely when a new owner takes the firm over (Basu et al. 2009).

Losing this personally owned goodwill would be a serious problem so new owners might try to keep as much of it as possible. Nevertheless, if those were transferable, taxation could be completely different. If the shares were held by a family-owned wealth management company or the sale of the firm would be structured as an asset sale (instead of sales of shares), any income would be taxed first by corporate income tax then by personal income tax of the owner. At the same time, personal goodwill (and 
any assets owned personally like a brand name) sold would only be taxed under the personal income scheme (Bhaumik-Dimova 2015).

Introducing different sources of funds to the operation of family businesses is unavoidable, and - with clever design - is beneficial. Vadnjal and Glas (2008) argue that family businesses need to understand that insisting on the self-sufficient manner of financing their business may result in limited growth and constraints hindering further extension of their operation. This would also limit creating a solid foundation for successful generational transition of family businesses.

\section{Use of accounting information for planning in the family businesses context}

Family firms have unique characteristics that explain why their practices are different from those of non-family firms. These unique characteristics include a concentrated ownership in the hands of the controlling family. Out of this fact rises the power of the controlling family which is the basis to pursue their goals, to protect the involvement of the family in the governance of the firm, to serve the interest of the controlling family in the long-term survival of the firm, which also may be based on the close relationship between managers and the family. Finally, we have to pay attention to the relevance of noneconomic factors such as reputation, or the emotional attachment of the family to the business (Carrera 2017).

Maintaining financial records in good quality and transparent manner is essential for the successful financial management of family businesses. In this context, the dayto-day financial activities like money management are necessary means for maintaining long-term financial security (Capoor et al. 2004).

However, several family specific obstacles can be identified when financial planning is concerned (Keasey et al. 2015). Family business owners typically do not have appropriate knowledge of accounting disciplines, such as management accounting and financial accounting. Accounting is one of the areas where family business owners face limitations of their scope of relevant accounting framework. From a theoretical point of view, studies on accounting and reporting issues in family businesses have mostly adopted an agency theory perspective, probably because agency theory has traditionally been the dominant framework in accounting research. Only a limited number of contributions have used alternative (or complementary) theories such as the stewardship theory, which give prominence to noneconomic factors that shape family firms management (Prencipe et al. 2014). 
In general, planning involves establishing the objectives of an organisation and formulating relevant strategies that can be used to achieve those objectives in family firms. In this regards, planning can be short-term (tactical planning) or long-term (strategic planning) (Prencipe et al. 2014).

Strategic planning, of most importance, is a managerial tool used to formulate business strategy. This process requires managers to collect data, analyse, reflect, conceptualize, construct alternatives and evaluate them using business forecasting to steer the company from its current state to a more advantageous/desired state (Mazzola et al. 2008). It could become an important developmental tool for the owner-manager of the family business, especially in case of a change in ownership (i. e. succession).

Decision-making involves the consideration of information in making informed decisions. In most situations taking a decision includes a choice between two or more alternatives. Using satisfiability as a principal approach to planning has many advantages (Huang et al. 2015). During the decision making process managers use the information related to actual results to reassess and amend their original budgets, measurers or plans. The next phase in plan implementation is the so called 'concept evaluation'. This phase involves evaluating the concepts according to the requirements and opting for the most suitable one. This step has to involve considerations for the customer as well (Schmidt et al. 2015).

For many family businesses, developing a business planning process has substantial value. It may, for example, create an opportunity to address a change in the family and business systems. For businesses that have become stagnant over the years, strategic business planning discussions can revitalize operations (Carlock-Ward 2001). For a family challenged by transitions in ownership or control, it begins a process of creating new understandings and agreements. In a period of family conflicts, planning creates a vehicle to reconnect with values and relationships.

The management prepares a plan, which is put into action by the executives who have control over the input resources (labour, money, materials, equipment etc.). Output from operations is measured and reported (feedback) to management, and actual results are compared to the plan. This process is shaped by the control reports. Managers take corrective action, where appropriate, especially in the case of exceptionally bad or surprisingly good outcomes (Dékán et al. 2010). Feedback can also be used to revise plans or prepare the plan for the next period. The development of this kind of an effective planning process will help the family focus on the business and create new strategies to revitalize the company and promote future growth over years and generations (Carlock-Ward 2001). 
Table 1: The managerial processes of planning, decision making and control

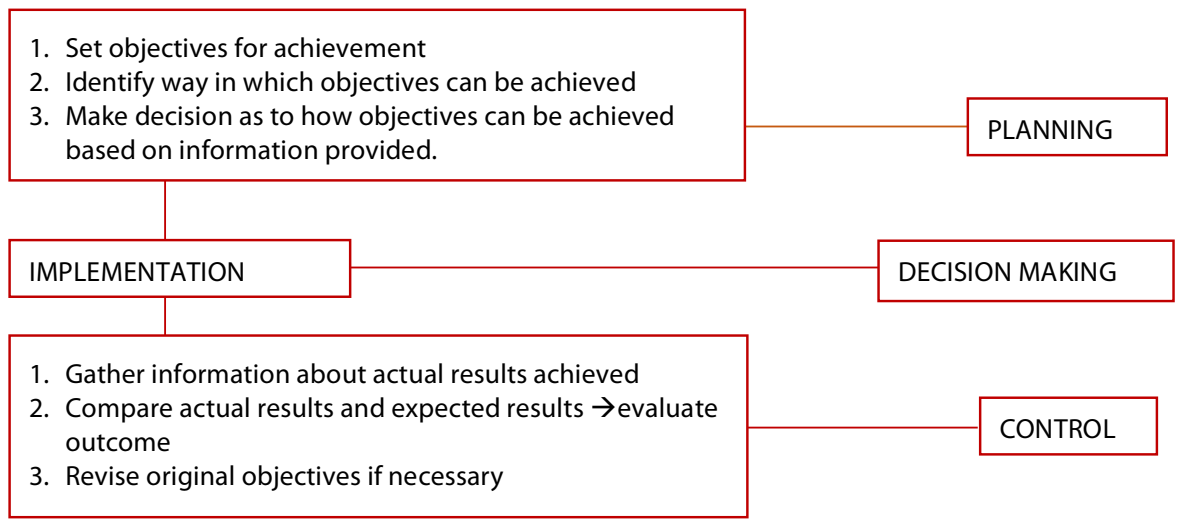

Source: Kaplan Financial Knowledge Bank, Management Accounting (2017)

Concerning the implementation, responsibility centres, cost centres, profit centres, investment centres and/or revenue centres are distinguished in the company. The responsibility centre is a separate part of the business where managers bear personal responsibility for the performance.

The cost centre is a production or service location, function, activity or item of equipment whose costs are identified and recorded. (For example, for a paint manufacturer cost centre might be: mixing and packing department, administration or selling and marketing department; whereas for an accountancy firm: audit, taxation, accountancy, word processing, administration, canteen may represent cost centres.) The cost centre managers need to have information about costs that are incurred and charged to their cost centres. The performance of a cost centre manager is judged on how the cost targets have been achieved.

The profit centre is a part of the business, in which both the costs incurred and the revenues earned are identified. This kind of profit centres is often found in large organisations with divisions, and each division is treated as a profit centre. However, in each profit centre there could be several costs centres and revenue centres. In this regard the performance of the profit manager is measured in terms of profits made by the centre; the manager must therefore be responsible for both costs and revenues and in a position to plan and control both. The data and information relating to both costs and revenues must be collected and allocated to the relevant profit centres. 
Regarding the investment centres, managers are responsible for investment decisions as well as those affecting costs and revenues, they are therefore accountable for the performance of capital employed as well as profits (costs and revenues). The performance of investment centres is measured in terms of profits earned relative to the capital invested (employed). This is known as ROCE (return on capital employed) $=$ Net profit/ Capital employed

Revenue centres represent a part of the organisation that earn sales revenue. They are similar to cost centres but only accountable for revenues rather than costs. Revenue centres are generally associated with selling activities, for example regional sales managers may have responsibility for regional sales revenues generated; and each regional manager would probably have sales targets to reach and would be held responsible for reaching these targets. The sales revenues earned have to be tracked back to individual (regional) revenue centres so that the performance of individual revenue centre managers could be assessed.

\section{Design and implementation of the funding mix}

The above mentioned organizational and performance evaluation practices are essential to provide the preconditions for managing the profit generating capability of the firms, which is crucial for raising external sources of fund (Sági 2007). Fama and French (2005) points out that profitability and growth characteristics of firms are central to their financing decisions, since valuable growth opportunities indicate how much investment a firm may need. Profitability also reflects to what extent these investment needs can be funded internally. However, while it is important to keep company's cash flow healthy, signing a bad financing agreement could hamper the business growth for years to come. It is very important to overview the forms and the main characteristics of financing and their impact on enterprise performance.

In general, as a family business is growing by increasing its sales turnover, by increasing the number of employees. On this way the firms operations are also becoming more structured, and sometimes invites identical funding solutions (Kozár 2013). As the firm is also generating more profit over the years, more and more funding sources are becoming available. Part of the external funds are raised from commercial trading partners and their institutions (Kozár-Suták 2012), in some cases in an institutional, standardised way (Kozár-Suták 2011). Start-up businesses rarely have the pleasure and luxury of sufficient funds to sustain their current and planned business expenditures. However, they need to obtain sufficient funds in order to compete in the industry, and 
must therefore look to external sources of finance to meet their business obligations. In their start-up phase, family businesses usually earn insufficient profits and week cash flow, and are short of assets to be placed as collaterals. A stable profit and cash flow generating capability only occur when the company enters the growing and maturing phase. Graph I shows the scope of funds, available as the business earns an increasing amount of revenues and profits.

\section{Graph 1: Access to sources of funds}

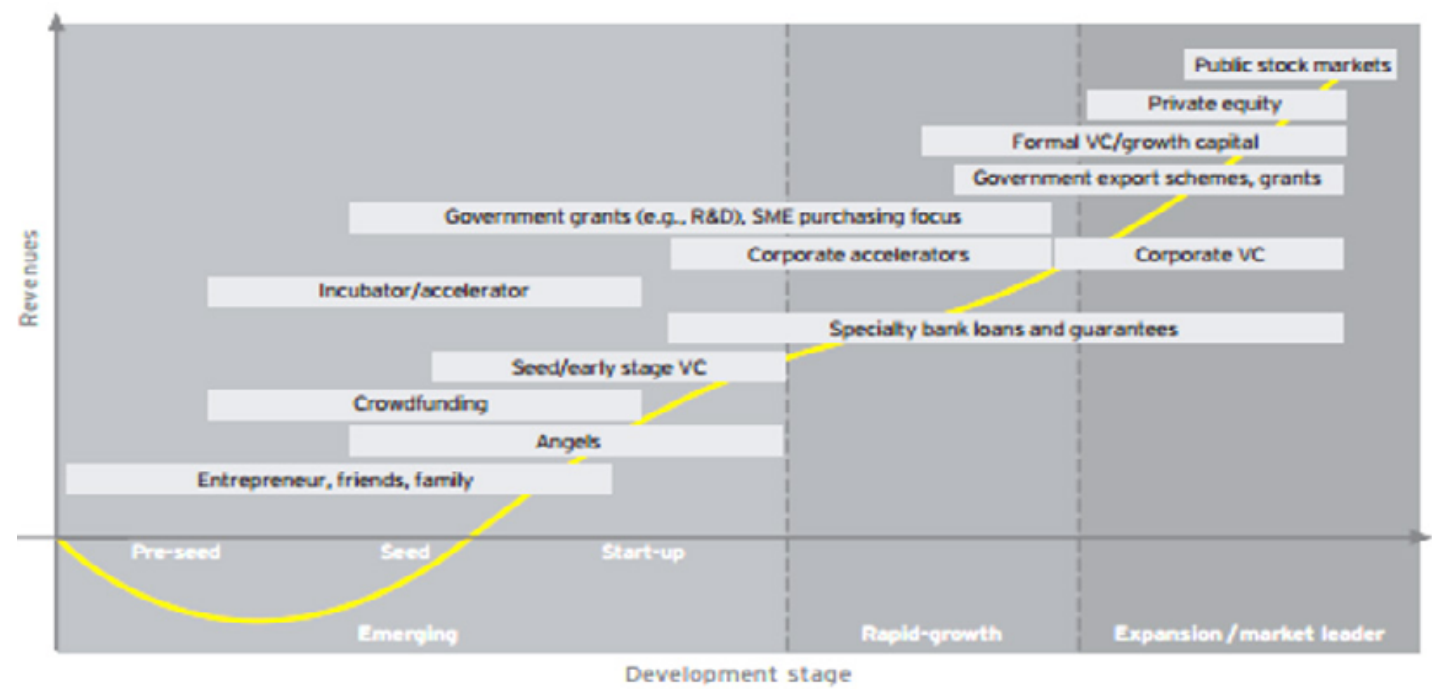

Source: Damodaran (2015: 13)

\section{Venture and equity capital}

Private equity and venture capital companies are ready to invest in a company at any time of its lifecycle but usually certain funds specialize on starting and matured companies (Konecsny et al. 2012). At this point distinction should be made between private equity and venture capital.

Private Equity provides capital to companies not quoted in the stock exchange. Usually this type of source is used to finance the development of products, the introduction of technologies, the expansion of current assets, acquisitions to stabilize the company's balance sheet. This type of investment usually modifies the ownership - and eventually the leadership - of the company and it can be used in successions as well. Private equity investors normally are focusing on more developed companies and usually in- 
vest higher amounts. Mostly the buyout and turnaround type transactions are represented by them.

Venture capital is also a form of investment that funds companies in the early stages such as seed, start-up and later stage ventures (Konecsny-Hegedüs 2013). As in early stage phases, the risk is above average, consequently investors expect higher returns as well.

The main characteristics of the different types of capital investment are summarized below:

\section{Early stage (venture capital)}

- Seed capital for helping to evolve the business concept, prepare the business plan, finance initial research and develop or prepare prototypes before the business really start production.

- Start-up financing normally addresses the phase of product development, market research, in early stage of operation of companies.

\section{Later stage (pivate equity)}

- Growth capital for financing the expansion or the acquisition of a company.

- Turnaround capital for acquiring of a mature company to restructure and reorganize it.

- Buy-out financing for acquisition of a company or a business line, including Management Buy-Out (MBO), Management Buy-In (MBI), Institutional BuyOut (IBO), Leveraged Buy-Out (LBO).

Finally it is worth to look at the exit stage and the means, if an investor would like to sell its investment in the company. Such a transaction can be executed by MBO, the inclusion of another investor or the Initial Public Offering (IPO), which is the first sale of stocks by a private company to the public.

\section{Family loans - personal debt for financing a business}

Many entrepreneurs launch their undertakings by borrowing money from friends and relatives. Such individuals are more likely to provide flexible terms of repayment than banks or other lenders and may be more willing to invest in an unproven business idea, based upon their personal knowledge and relationship with the entrepreneur (GamaGalvão 2012). 
A potential disadvantage is that friends and relatives may try to become involved in the management of the business. Business owners who wish to avoid such complications must use the same formal arrangements with relatives and friends as with more distant business associates. But this is not easy to carry out it in practice.

Founding a business is extremely risky (Kiss-Schuszter, 2014). Founding costs include legal costs (lawyer, company registration etc.), shareholder's capital and so on. If founders do not have enough money to cover all the costs but are committed to found the firm, they should get somehow the missing sum needed. Traditionally we may say that there are three sources: family, friends, and fools.

In that context fools are people or organisations who take the potential risks of default of a new business. That risk is enormous, most new businesses do not live 2-4 years and do not earn any profits either. But in some cases, if the idea is good enough and the business starts taking off and grow, the return may be high.

A new development in fundraising is crowdfunding. Crowdfunding is an online hub, where individuals from all around the world can donate for a project. Although most individuals pay a relatively low amount of money, say 5-10 euros, due to the high number of participating individuals, the necessary capital for the project can be gathered in a matter of months. In return for support, individuals get a specific advantage that depends on the project owners. Donors paying say 5-10 euros get the experience of helping a project but those paying 20-25 euros a basic edition of the product and those paying 50 euros a dedicated or a premium edition may be the reward for their donation.

Others use crowdfunding to finance their own personal needs and promise interest and repayment. This represent a crowdfunded loan, where the borrowed money comes from a number of different people and the borrower pays interest as well.

\section{Bank loans, overdrafts}

Borrowing money from the bank is the traditional method used by businesses to raise funds for their current and future projects. Interest must normally be paid on any money borrowed from the bank. There are different forms of bank loans available to businesses. It is generally more difficult for new businesses to get a loan with relatively low interest rates.

There is an endless range of loans on offer that suit all types of businesses. These vary according to: 
- the amount required by the business;

- the length of time over which the business will repay the loan;

- the type of interest rate being charged by the bank (e. g. fixed or variable).

Choosing the right type of interest rate is very important for the business in the long run. This can be difficult, since both fixed and variable rates have advantages and disadvantages. For example, taking out a fixed rate loan implies that the company can accurately predict the size of the monthly repayments. On the other hand, repayments on a variable rate loan can fluctuate (Sági-Sóvágó, 2002).

An overdraft is the most common form of loans available to businesses in the short term. An overdraft is a flexible method to use in order to finance a business shortfall over a short period. The money can be drawn out by the business fairly quickly and repaid over the period agreed with the bank; though interest rates and ease of borrowing will depend on the state of the business and on the history of the company. If a company has no previous track record, banks require some form of collateral, perhaps involving the assets of the business or the personal property of the owner. Where a business uses its assets to secure an overdraft, this clearly limits its ability to sell these assets or to use them to acquire any other financial sources (Sági, 2017, 2018). However, if the business has a good track record, an unsecured overdraft facility may be arranged. One of the main advantages of this type of borrowing is that the debt can be paid off at any time without penalty. On the other hand, an overdraft is repayable on demand from the bank. Since overdrafts are given and the interest rate set according to the status of the individual account, new customers are normally charged more than long-standing customers (Neszmélyi 2017).

\section{Bonds}

Corporate bonds are immaterialised financial instruments. Similar to loans and other debt instruments (for example bill of exchange or commercial loans) corporate bonds are external source of finance. Accordingly, corporate bonds play quite a similar role in financing the business. The similarities between bonds and loans are as follows:

- interest is tax deductible;

- interest rates and dates of interest payments and capital repayment(s) are clearly stated; 
- investor's major risks are related to the insolvency of the firm (repayments of interest and/or capital). In case of default on interest and/or capital payments investors have the same rights as banks, they may appropriate the assets pledged and sell them, in order to obtain the owed amount.

There are differences also. Bond financing of firms means to get money directly from the capital market. In this way the firm does not borrow money from a particular institution or person but from a group of investors who can then sell (trade with) these bonds as well. Bonds are traded in most cases on the stock exchange or OTC markets.

Bonds can be classified based on several characteristics. The most important characteristics and types of bonds are the following bonds:

- Interest rate: fixed rate, variable rate (rate changes in a predetermined manner), floating rate (rate linked to a base rate like LIBOR).

- Interest payment: none (zero coupon), regular (semi-annual, annual), accumulated interest payment at maturity (bullet).

- Principal payment: regular equal instalments, bullet payment (at maturity), annuity bond (interest and principal payment made regularly totalling each time to the same amount).

- Attached option type: none (conventional bond), puttable (holder may sell back to issues under pre-set condition), callable (issuer may repurchase under pre-set conditions), and convertible (owner has the right to convert bond to common share at a given price and at a specified date).

The theoretical price of a bond defines a price determined on an efficient market. The theoretical value of an asset is calculated as the sum of present value of future cash flows (interests and principal payments).

In the United States a much larger proportion of firms use capital market to finance their operations but in the continental Europe it is typical only for bigger companies. Therefore, bond financing is pretty much irrelevant for family firms.

\section{Initial public offering}

Initial public offering (IPO) means that the investors can purchase the company's shares on the stock exchange for the first time. Normally an investment bank or an agent qualified for taking the role of underwriter advises and manages the process for 
a fee payed by the company. To qualify for an IPO the company with the help of its underwriter must prepare a number of different documents, including a prospectus, to convince the authorities and potential investors that shares are worth buying at the pre-set pricing. These papers offer a lot of information about the company and about its prospects, based on which investors may attempt to set their own price expectations and enter the procedure of buying the shares themselves.

If the estimated value of the share is higher than the offer price, they will buy it, in the opposite case, they will not. That is why, in order to assure the success of an IPO, former owners may agree to offer the new shares with some discount (at a lower price than the estimated intrinsic value). In case of an IPO different investors may have markedly different interests (Cirillo et al. 2015).

The investment bank acting as underwriter for the transaction takes the responsibility to buy all shares not sold in the IPO. Thus, it is in their interest to set a low price, because it reduces the risk that they will not be able to sell all the shares. In addition, even if they have to buy at the time of the IPO, when later the price increases, the bank can realise a profit by selling those shares later.

The current owners want to sell shares at a high share price. If the IPO is not only about issuing new shares, and the owners sell some of their own stake, then they may be interested in overestimating the future economic prospects of the company to influence expectations and boost the current selling price.

At the same time, investors seek a good deal, e.g. a great outlook at a less than fair offer price. Due to this, if a relatively unknown company wants to start as a success story on the stock exchange, it is often advised to offer shares at IPO with a discount of about 15-20 percent at least.

\section{Conclusions}

There are several motives for family businesses when making decisions on the proposed timing and form of introducing new sources of funds to their operation. One motive of family firms that is likely to influence their financing decisions is the willingness of the main owner to dilute his or her control over the business (Keasey et al. 2015). The organization's life-cycle stages represent another factor in financial decisions.

In case of an existing business, owners can use several sources of funding, such as the retained earnings, loans from family member, bank loans or various types of equity issues. However, most authors indicated that different sources of funding may have different 'popularity' among companies reflecting their preferences. For example, 
large listed companies prefer bond financing to issuing new shares. The pecking-ordertheory explains the expected ranking of sources. In case of family businesses the ranking is the following: company profits, loans from family member, loans from banks and others, equity of owners, equity of new family members, and equity of new external investors.

Enlisting the main sources of external funds, including the venture and equity capital, we noted that - as opposite to bank financing - bond financing is usually hard to get for a family business in Europe.

Our results suggest that family businesses normally do not have access to foreign capital, and they are reluctant to use other forms of debt which would involve such obligations, that potentially would limit their independence. In most European countries family firms often forgo growth opportunities due to a lack of internally generated funds or own equity.

\section{References}

Baek, J. - Kim, J. (2015): Cofounders and the value of family firms. Emerging Markets Finance and Trade, 51, 20-33. https://doi.org/10.1080/1540496x.2015.1039899.

Basco, R. (2015): Family business and regional development - A theoretical model of regional familiness. Journal of Family Business Strategy, 6, Family Business and Regional Development, 259-271. https://doi.org/10.1016/j.jfbs.2015.04.004.

Basco, R. (2014): Exploring the influence of the family upon firm performance: Does strategic behaviour matter? International Small Business Journal, (32)8, 967-995. https://doi.org/10.1177/0266242613484946.

Basu, N. - Dimitrova, L. - Paeglis, I. (2009): Family control and dilution in mergers. Journal of Banking and Finance, 33, 829-841.

https://doi.org/10.1016/j.jbankfin.2008.09.017.

Bhaumik, S. K. - Dimova, R. (2015): Family Involvement and Firm Performance. In How Family Firms Differ. London; Palgrave Macmillan, 69-94.

https://doi.org/10.1057/9781137473585 4.

Capoor, J. R. - Dlabay, L. R. - Hughes, R. J. (2004): Personal Finance. (Seventh ed.) McGraw Hill-Irwin.

Carlock, R. S. - Ward, J. L. (2001): Strategic Planning for the Family Business - Parallel Planning to Unify the Family and Business. Palgrave Macmillan UK.

https://doi.org/10.1057/9780230508750. 
Carrera, N. (2017): What do we know about accounting in family firms? Journal of Evolutionary Studies in Business, (2)2, 97-159.

Cirillo, A. - Romano, M. - Ardovino, O. (2015): Does family involvement foster IPO value? Empirical analysis on Italian stock market. Management Decision, (53)5, 1125-1154. https://doi.org/10.1108/md-11-2014-0639.

Damodaran, A. (2015): The corporate life cycle: Growing up is hard to do! http://people.stern.nyu.edu/adamodar/pdfiles/country/corporatelifecycleLongX.pdf.

Dékán, T. - Nábrádi, A. - Bács, Z. - Kozár, L. (2010): Understanding of production cost variances in hectic business environment. In: Zhang, M. (ed.): Economics Busines and Management International Proceedings of Economics Development and Research. Singapore: IACSIT Press, 210-212.

Eleni, S. - George, K. - Alexis, F. (2007): Downsizing and Stakeholder Orientation among the Fortune 500: Does FAMILY OWNERSHIP MATTER? Journal of Business Ethics, 2, 149-162. https://doi.org/10.1007/s10551-006-9162-x.

Fama, E. - French, K. (2005): Financing decisions: Who issues stock? Journal of Financial Economics, 76, 549-582. https://doi.org/10.1016/j.jfineco.2004.10.003.

Gama, A. - Galvão, J. (2012): Performance, valuation and capital structure: Survey of family firms. Corporate Governance, (12)2, 199-214. https://doi.org/10.1108/14720701211214089.

Goel, S. - He, X. - Karri, R. (2011): Family involvement in a hierarchical culture: Effect of dispersion of family ownership control and family member tenure on firm performance in Chinese family owned firms. Journal of Family Business Strategy, 2, 199-206. https://doi.org/10.1016/j.jfbs.2011.10.003.

Haynes, G. W. - Walker, R. - Rowe, B. R. - Hong, G. S. (1999): The intermingling of business and family finances in family-owned businesses. Family Business Review, (12)3, 225-239. https://doi.org/10.1111/j.1741-6248.1999.00225.x.

Heidrich, B. - Németh, K. - Chandler, N. (2016): Running in the family - Paternalism and familiness in the development of family business. Vezetéstudomány, (47)11, 70-82. https://doi.org/10.14267/veztud.2016.11.08.

Huang, M. - Li, P. - Meschke, F. - Guthrie, J. (2015): Family firms, employee satisfaction, and corporate performance. Journal of Corporate Finance, 34, 108-127. https://doi.org/10.1016/j.jcorpfin.2015.08.002.

Jaskiewicz, P. - Luchak, A. A. (2013): Explaining performance differences between family firms with family and nonfamily CEOs: It's the nature of the tie to the family that counts! Entrepreneurship Theory and Practice, (37)6, 1361-1367.

https://doi.org/10.1111/etap.12070. 
Keasey, K. - Martinez, B. - Pindado, J. (2015): Young family firms: Financing decisions and the willingness to dilute control. Journal of Corporate Finance, 34, 47-63. https://doi.org/10.1016/j.jcorpfin.2015.07.014.

Kiss, G. D. - Kuba, P. (2009): Diverzifikáció a komplex tőkepiacokon - Az emberi tényező hatása a tőkepiacok müködésére. Hitelintézeti Szemle/Financial and Economic Review, 8(1), 25-48.

http://www.bankszovetseg.hu/anyag/feltoltott/HSz2009 1 Kiss Kuba 25 48.pdf.

Kiss, G. D. - Schuszter, T. (2014): Miben különböznek a devizaalapú hitelek devizái? Pénzügyi Szemle/Public Finance Quarterly, 59(2), 187-206. https://www.asz.hu/hu/ penzugyi-szemle/miben-kulonboznek-a-devizaalapu-hitelek-devizai.

Konecsny, J. - Hegedüs, Sz. (2013): Comparative analysis between the European and United States' venture capital market. In Szendrő, K. - Soós, M. (eds.): Proceedings of the 4th International Conference of Economic Sciences. Kaposvár University, 471-477.

Konecsny, J. - Havay, D. - Hegedűs, Sz. (2012): Venture capital and private equity investments in the Central-Eastern European region. Journal of International Scientific Publication: Economy and Business, (6)2, 211-220.

Kozár, L. (2013): Commodity Financing, Based on Special Purpose Company. Third AGRIMBA AVA Congress. Budva, Montenegro, 30-34.

Kozár, L. - Suták, P. (2012): The role of trading-house structure in commodity financing. The Business Review (Cambridge), (20)2, 202-208.

Kozár, L. - Suták, P. (2011): Trade finance, based on functions of market institutions. In Knego, N. - Renko, S. - Knezevic, B. (eds.): Distributive Trade as See and Cee Development Driver: Proceedings of the International Scientific Conference, 35-35.

La Porta, R. - Lopez-De-Silane, F. - Shleifer, A. - Vishny, R. (1997): Trust in large organizations. American Economic Review, (87)2, 333-338.

https://doi.org/10.3386/w5864.

Lins, K. - Volpin, P. - Wagner, H. (2013): Does family control matter? International evidence from the 2008-2009 financial crisis. Review of Financial Studies, (26)10, 2583-2619. https://doi.org/10.1093/rfs/hht044.

Mazzola, P. - Marchisio, G. - Astrachan, J. (2008): Strategic planning in family business: A powerful developmental tool for the next generation. Family Business Review, (21)3, 239-258. https://doi.org/10.1177/08944865080210030106.

Motylska-Kuzma, A. (2017): The financial decisions of family businesses. Journal of Family Business Management, (7)3, 351-373.

https://doi.org/10.1108/jfbm-07-2017-0019. 
Neszmélyi, Gy. I. (2017): Family-based farming - can it be competitive? Dilemmas on the farm-size in Hungary - Successful patterns in the world: Denmark and South Korea. Taiwanese Agricultural Economic Review, (23)2, 131-161.

Pérez Rodríguez, M. J. - Basco, R. (2011): The cognitive legitimacy of the family business field. Family Business Review, (24)4, 322-342.

https://doi.org/10.1177/0894486511416356.

Prencipe, A. - Bar-Yosef, S. - Dekker, H. C. (2014): Accounting research in family firms: Theoretical and empirical challenges. European Accounting Review, (23)3, 361-385. https://doi.org/10.1080/09638180.2014.895621.

Reilly, F. R. (2016): Distinguishing personal goodwill from entity goodwill in the valuation of a closely held corporation. Insights, 54-60. http://www.willamette.com/insights journal/16/winter 2016 6.pdf.

Sági J. (2007): Banktan. Saldo Pénzügyi Tanácsadó és Informatikai Rt.

Sági, J. (2017): Credit guarantees in sme lending, role, interpretation and valuation in financial and accounting terms. Economics Management Innovation, (9)3, 62-70. http://emijournal.cz/wp-content/uploads/2017/12/06 Credit-guarantees-in-SMElending.pdf.

Sági J. (2018): Hitelgaranciák. Jura, 1, 411-418. http://jura.ajk.pte.hu/JURA 2018 1.pdf. Sági J. - Sóvágó L. (2002): Lakossági bankügyletek. Unió, BGF Kereskedelmi, Vendéglátóipari és Idegenforgalmi Főiskolai Kar, Finance Oktatási és Kutatási Alapítvány.

Schmidt, D. M. - Malaschewski, O. - Mörtl, M. (2015): Decision-making Process for Product Planning of Product-Service Systems. 7th Industrial Product-Service Systems Conference - PSS, industry transformation for sustainability and business; Procedia CIRP 30, 468-473. https://doi.org/10.1016/j.procir.2015.02.142.

Stafford, K. - Danes, S. M. - Haynes, G. W. (2013): Long-term family firm survival and growth considering owning family adaptive capacity and federal disaster assistance receipt. Journal of Family Business Strategy, (4)3, 188-200.

https://doi.org/10.1016/j.jfbs.2013.06.002.

Suleimankadieva, A. E. - Pilipenko, V. I. - Sági, J. (2019): Knowledge Company: Approaches to Assessing New Knowledge and Representation it to Society. Procedia Computer Science, 150, 730-736. https://doi.org/10.1016/j.procs.2019.02.011.

Vadnjal, J. - Glas, M. (2008): Financing of family and non-family enterprises: Is it really different? Electronic Journal of Family Business Studies (EJFBS), (2)1, 39-57.

Vadnjal, J. - Kociper, T. - Letonja, M. (2010): Family business research in Slovenia: Relevant issues for other transition economies. Annals of Eftimie Murgu University Resita, Fascicle II, Economic Studies, 166-179. 
Villalonga, B. - Amit, R. (2006): How do family ownership, control and management affect firm value? Journal of Financial Economics, 80, 385-417. https://doi.org/10.2139/ssrn.556032.

This paper was written as part of the project 2016-1-HU01-KA203-022930) ERASMUS+ Strategic Partnership for Higher Education with support of the European Commission. This publication reflects only the views held by the author, and the Commission cannot be held responsible for any use which may be made of the information contained therein. 